\title{
Isolated anorectal malformation
}

\author{
INSERM
}

\section{Source}

INSERM. (1999). Orphanet: an online rare disease and orphan drug data base. Isolated anorectalmalformation. ORPHA:557

Anorectal malformations (ARM) comprise a wide spectrum of malformations involving the distal anus and rectum as well as the urinary and genital tracts, which can affect boys and girls. 